\title{
Elevated toxic effect of sediments on growth of the harmful dinoflagellate Cochlodinium polykrikoides under high $\mathrm{CO}_{2}$
}

\author{
Alexandra R. Bausch ${ }^{1,2, *}$, Fulvio Boatta ${ }^{3}$, Peter L. Morton ${ }^{4}$, Kali T. McKee ${ }^{1}$, \\ Robert F. Anderson ${ }^{1,2}$, Helga R. Gomes ${ }^{1}$, Joaquim I. Goes ${ }^{1}$ \\ ${ }^{1}$ Lamont-Doherty Earth Observatory, Columbia University, Palisades, NY 10964, USA \\ ${ }^{2}$ Department of Earth and Environmental Sciences, Columbia University, Palisades, NY 10964, USA \\ ${ }^{3}$ National Institute of Geophysics and Volcanology (INGV), 90146 Palermo, Italy \\ ${ }^{4}$ National High Magnetic Field Laboratory, Florida State University, Tallahassee, FL 32310, USA
}

\begin{abstract}
Ocean acidification will likely have significant impacts on phytoplankton growth in marine ecosystems over the course of this century. Coastal waters, which can be strongly influenced by suspended sediments, can also be particularly sensitive to ocean acidification. While the individual effects of trace metal inputs and ocean acidification have each been well documented, the combined effects of high trace metal concentrations due to mobilization from sediments and high dissolved $\mathrm{CO}_{2}$ concentrations (low seawater $\mathrm{pH}$ ) on the growth of marine phytoplankton are not known. In this study, a batch culture experiment was performed using the model organism Cochlodinium polykrikoides over $35 \mathrm{~d}$ under a range of $\mathrm{CO}_{2}$ concentrations $(400,800$, and 1200 ppmv) following sediment additions. At high $\mathrm{CO}_{2}$, dissolved iron ( $\mathrm{Fe}$ ) and nickel (Ni) concentrations increased over time. Dissolved Ni concentrations were significantly higher after $35 \mathrm{~d}$ at 1200 ppmv $\mathrm{CO}_{2}$ compared to the other treatments and corresponded to significant decreases in $C$. polykrikoides growth rates. In addition, a toxicity bioassay experiment was performed over $29 \mathrm{~d}$ under a range of $\mathrm{Ni}$ or cadmium $(\mathrm{Cd})$ concentrations at ambient $\mathrm{CO}_{2}$. The growth responses of $C$. polykrikoides were dose-dependent and were significantly lower under increasing $\mathrm{Ni}$ or $\mathrm{Cd}$ concentrations. The findings suggest that a combination of elevated total dissolved Ni supplied from sediments and high $\mathrm{CO}_{2}$ conditions could suppress the growth rates and photosynthesis of $C$. polykrikoides in coastal marine ecosystems. This is the first study to examine the synergistic, toxic effects of lithogenic trace metals and $\mathrm{CO}_{2}$ on phytoplankton growth.
\end{abstract}

KEY WORDS: Cochlodinium polykrikoides · Sediment · Toxicity · Carbon dioxide · Nickel · Cadmium $\cdot$ Trace metals $\cdot$ Ocean acidification

Resale or republication not permitted without written consent of the publisher

\section{INTRODUCTION}

Increasing atmospheric $\mathrm{CO}_{2}$ concentrations are expected to strongly impact both marine organisms and ecosystem processes via ocean acidification (Doney et al. 2009). By 2100, global atmospheric $\mathrm{CO}_{2}$ concentrations are projected to reach up to 1150 parts per million by volume (ppmv; IPCC 2013), causing sea surface $\mathrm{pH}$ to decrease by $0.3-0.5$ units (Caldeira \& Wickett 2005). Although the biological responses to decreased seawater $\mathrm{pH}$ are complex, variable, and species-specific, ocean acidification will likely have profound effects on many marine calcifying organisms, on some noncalcifying phytoplankton, and more generally, on marine food webs and ecosystems (Guinotte \& Fabry 2008, Doney et al. 2009, Connell \& Russell 2010).

Some coastal waters may be particularly susceptible to ocean acidification over the course of this century, especially in regions with high riverine inputs or 
strong mixing (Strong et al. 2014). Such systems can have high concentrations of total suspended solids due to inputs of lithogenic particles in freshwater or resuspension of bottom sediments (Geyer et al. 2004). The Hudson River estuary (New York, USA), the Eel River shelf (California, USA), and the Amazon shelf (Brazil) can all experience suspended sediment concentrations in excess of $1000 \mathrm{mg} \mathrm{l}^{-1}$ (Geyer et al. 2004). On a global scale, changes in climate and land use may increase riverine sediment inputs to coastal marine ecosystems by the end of this century (Yang et al. 2003, Ito 2007).

Coastal areas of the Persian Gulf may be vulnerable to the interactive effects of ocean acidification and lithogenic particle loads. The Persian Gulf marine ecosystem is predicted to have one of the highest cumulative anthropogenic impacts by the end of this century (Halpern et al. 2008). Additionally, coastal waters in the region are strongly influenced by high concentrations of suspended sediments ranging from 125 to $2295 \mathrm{mg} \mathrm{l}^{-1}$ from the Shatt al-Arab River (Gaillardet et al. 1999, Al-Yamani 2008) and, to a lesser extent, atmospherically forced mineral dust from the Arabian Peninsula (Tindale \& Pease 1999, Mackey et al. 2010). Over the course of this century, high concentrations of both atmospheric $\mathrm{CO}_{2}$ and suspended lithogenic particles will likely impact marine organisms within the ecosystem.

Lithogenic particles play an important role in carbon cycling, storage, and climate (Turner \& Millward 2002, Jickells et al. 2005, Mahowald et al. 2010). Sediments and dust contain iron ( $\mathrm{Fe}$; Martin 1990, Duce \& Tindale 1991), as well as other bioactive trace metals such as nickel (Ni) and cadmium (Cd; Modaihsh 1997, Sunda et al. 2005, Mackey et al. 2012). The bioactive trace metals mobilized from lithogenic particles can stimulate phytoplankton growth at relatively low concentrations (Morel \& Price 2003, Ho et al. 2013, Twining \& Baines 2013). In addition, lithogenic particles (Moore et al. 2009, Srinivas \& Sarin 2013) and trace metals such as Ni (Ho 2013) have been shown to stimulate oceanic nitrogen fixation. However, some trace metals supplied by mineral particles can also be toxic at high concentrations (Paytan et al. 2009, Jordi et al. 2012). Trace elements such as $\mathrm{Cd}$, copper $(\mathrm{Cu})$, and lead $(\mathrm{Pb})$ have been shown to negatively affect the growth of marine phytoplankton (Brand et al. 1986, Echeveste et al. 2012, Herzi et al. 2013). Sub-lethal toxic effects of $\mathrm{Cu}$ and $\mathrm{Pb}$ have been described for the harmful dinoflagellate Cochlodinium polykrikoides (Ebenezer \& Ki 2012). Despite varying sensitivities and growth responses to trace metals among phytoplankton species (Sunda
1989), potential future changes in lithogenic particle inputs could significantly impact marine biogeochemical dynamics (Mahowald et al. 2010).

While many studies have examined the individual effects of $\mathrm{CO}_{2}$ or trace metals on phytoplankton physiology (e.g. Morel \& Price 2003, Doney et al. 2009), few studies have explored the combined interactions of ocean acidification and trace metal chemistry on phytoplankton growth (Millero et al. 2009). Ocean acidification can impact the biogeochemistry of lithogenic trace metals by altering their solubility and speciation, including their capacity to form complexes with organic ligands (Eggleton \& Thomas 2004, Millero et al. 2009, Hoffmann et al. 2012). Decreased seawater $\mathrm{pH}$ has been shown to alter the chemical speciation of $\mathrm{Fe}$, leading to significant impacts on the uptake rates of Fe by phytoplankton (Shi et al. 2010). Both seawater $\mathrm{pH}$ and complexing agents have been shown to impact the bioavailability and uptake rates of zinc (Zn) and Cd (Xu et al. 2012). In high-nutrient, low-chlorophyll (HNLC) waters of the North Pacific, ocean acidification has been shown to influence Fe uptake from desert dust deposition (Mélançon et al. 2015). However, no studies have examined the potential toxic effects of lithogenic trace metals on the growth of phytoplankton (e.g. C. polykrikoides) under varying ocean acidification scenarios. This is a critical area of research that requires attention (Hoffmann et al. 2012).

In the present study, the dinoflagellate C. polykrikoides was used as a model organism to assess the interactive effects of increasing atmospheric $\mathrm{CO}_{2}$ and trace metal release from sediments on the growth of a harmful algal bloom (HAB) species. C. polykrikoides blooms have been observed in the Persian Gulf and Sea of Oman (Richlen et al. 2010, Al-Azri et al. 2014), and have been associated with mass mortalities of fish and shellfish in the region (Al Gheilani et al. 2011, Saeedi et al. 2011). In the present study, sediments collected from Oman were added to batch cultures to assess the toxicity of lithogenic trace metals under 3 different $\mathrm{CO}_{2}$ conditions: 400 ppmv (current atmospheric levels), 800 ppmv (projected 'business-as-usual scenario' levels in 2100), and 1200 ppmv (projected 'worst-case scenario' levels in 2100; IPCC 2013). The concentrations of bioactive trace metals released from the sediments and the growth responses of the model organism C. polykrikoides were examined over $35 \mathrm{~d}$. In addition, a toxicity bioassay experiment was performed to assess C. polykrikoides growth responses under a range of concentrations of $\mathrm{Cd}$ or $\mathrm{Ni}$ ( 2 potentially toxic lithogenic trace metals) at ambient $\mathrm{CO}_{2}$ over $29 \mathrm{~d}$. 
The research objectives were threefold: (1) to assess the changes in trace metal concentrations released from sediments under high $\mathrm{CO}_{2}$, (2) to examine the physiological responses of $C$. polykrikoides to high suspended sediment loads under elevated $\mathrm{CO}_{2}$, and (3) to determine the toxicity responses of $C$. polykrikoides to $\mathrm{Cd}$ and Ni. Based on previous studies (e.g. Millero et al. 2009), the release of trace metals from sediment was predicted to increase under increasing $\mathrm{CO}_{2}$ (Hypothesis 1). In addition, based on other recent studies (e.g. Paytan et al. 2009), increased concentrations of dissolved lithogenic trace metals were predicted to negatively affect the growth of C. polykrikoides (Hypothesis 2). This is the first study to examine the synergistic, toxic effects of sediment on the growth of a HAB species under high $\mathrm{CO}_{2}$. It is also the first study to examine the toxicity responses of C. polykrikoides to $\mathrm{Ni}$ and $\mathrm{Cd}$. Such information is essential to improve understanding of the changing biogeochemical dynamics associated with anthropogenic ocean acidification in marine ecosystems.

\section{MATERIALS AND METHODS}

\section{Algal culture and media}

Culture isolates of Cochlodinium polykrikoides (strain CP1) came from Flanders Bay in Long Island, NY, USA (Gobler et al. 2008, Tang \& Gobler 2009). This culture strain (the 'American/Malaysian' ribotype) was the same strain as that identified in the Persian Gulf and Sea of Oman in 2008-2009 based on ribosomal RNA sequence data (Iwataki et al. 2008, Richlen et al. 2010). Cultures were maintained at a constant temperature of $24.7 \pm 0.04^{\circ} \mathrm{C}$ (mean \pm SEM) in an incubator fitted with a bank of $34 \mathrm{~W}$ cool white lights with a light intensity of $\sim 100 \mu \mathrm{mol}$ quanta $\mathrm{m}^{-2}$ $\mathrm{s}^{-1}$ and with a photoperiod of $11.5 \mathrm{~h}$ light: $12.5 \mathrm{~h}$ dark.

Seawater was collected from Corson's Inlet in Dennisville, NJ, USA (salinity 34), $0.2 \mu \mathrm{m}$ capsulefiltered, and autoclave-sterilized. Three types of modified L1 media (Guillard \& Hargraves 1993) were prepared using coastal seawater as the base: (1) media with no added trace metals, EDTA, or silicate, used for the $\mathrm{CO}_{2}$ /sediment incubation experiment (in all treatments including the reference cultures), (2) media with no added $\mathrm{Cd}$ or silicate, used for growing the cultures and for the Cd bioassay experiment, and (3) media with no added $\mathrm{Cd}, \mathrm{Ni}$, or silicate, used for the Ni bioassay experiment. Note that the media used in the bioassay experiment contained EDTA disodium salt dihydrate $\left(1.17 \times 10^{-5} \mathrm{M}\right)$, a synthetic chelator that binds to metal ions in media (Sunda et al. 2005).

All polycarbonate culture flasks and Teflon/Tygon tubing used for the incubation experiments were soaked in $5 \% \mathrm{HCl}$ (technical grade) for at least $3 \mathrm{~d}$ and rinsed with ultrapure water (Millipore Milli-Q). All Teflon bottles used for the collection and storage of trace metal samples were soaked in $2 \%$ detergent (Micro-90) for $1 \mathrm{~d}$, rinsed with deionized (DI) and ultrapure water, acid-soaked $(10 \% \mathrm{HCl}$, technical grade) for $3 \mathrm{~d}$, acid-soaked ( $1 \% \mathrm{HCl}$, reagent grade) for another $3 \mathrm{~d}$, rinsed with ultrapure water, and stored with acidified ultrapure water $(0.024 \mathrm{M} \mathrm{HCl}$, quartz-distilled).

\section{Sediment}

Sediment was obtained from an undisturbed, terrestrial source point near the coast in Muscat, Oman $\left(23.607^{\circ} \mathrm{N}, 58.595^{\circ} \mathrm{E}\right)$. The sediment particles were size-fractionated to collect the 60-100 $\mu \mathrm{m}$ fraction using acid-cleaned, sonicated synthetic nylon screens. This size fraction of particles was within the range of sediment grain sizes observed in the Persian Gulf (Emery 1956). The trace metal composition of the sediment was determined in the Class-1000/100 Geochemistry facilities at the National High Magnetic Field Laboratory (NHMFL; Tallahassee, FL, USA) via microwave digestion (CEM MARS Xpress) with nitric acid $\left(\mathrm{HNO}_{3}\right)$ and hydrofluoric acid $(\mathrm{HF})$, followed by quantification using high-resolution magnetic sector inductively coupled plasma-mass spectrometry (ICP-MS; Thermo ELEMENT 2; Morton et al. 2013). The trace metal composition of the sediment was compared to that of upper continental crust (Rudnick \& Gao 2003) and Oman ophiolite (Hanghøj et al. 2010; Table S1 in the Supplement at www.intres.com/articles/suppl/a080p139_supp.pdf).

\section{$\mathrm{CO}_{2} /$ sediment incubation experiment}

C. polykrikoides cultures were maintained in a total of $3 \mathrm{CO}_{2}$ treatments $(400,800$, and $1200 \mathrm{ppmv})$ in an ocean acidification experimental design consistent with recommendations from Cornwall \& Hurd (2016). Five days prior to the start of the experiment, the media in each of the reservoir headers were purged continuously using 3-component compressed gas mixtures of $\mathrm{CO}_{2}(400,800$, or $1200 \mathrm{ppmv}), 21 \%$ $\mathrm{O}_{2}$, and balance $\mathrm{N}_{2}$. One day prior to the start of the 
experiment, C. polykrikoides cells were centrifuged (300 RCF, 3 min), resuspended, and acclimated in L1 media with no added trace metals, EDTA, or silicate. At the start of the experiment, after the desired $\mathrm{pH}$ levels were maintained in the reservoirs, 11 of the compressed gas-amended media from each of the reservoir headers was carefully siphoned into each of 5 culture flasks per $\mathrm{CO}_{2}$ treatment. Aliquots of acclimated C. polykrikoides cells were then transferred into 3 experimental flasks (culture with sediment) and one reference flask (culture without sediment) per treatment to yield initial cell concentrations of 2.4 $\times 10^{3}$ cells $1^{-1}$ in each flask. Cell concentrations were low in order to prevent changes in $\mathrm{pH}$ or dissolved oxygen over time. Equal aliquots (500 mg) of the sizefractionated sediment were added to each of the 3 experimental flasks and 1 sediment blank flask (sediment only, no culture) per treatment. The flask containing only sediment was used as a blank for chlorophyll a (chl a) concentrations. The amount of sediment added in this incubation experiment was within the range of observed levels of suspended solids in coastal waters of the Persian Gulf (Gaillardet et al. 1999, Al-Yamani 2008).

The flasks were randomly positioned in the incubator and gently swirled at least once a day over the course of the $35 \mathrm{~d}$ batch culture incubation experiment. Cultures were maintained over an extended period of time, since trace metals have been shown to exhibit a broad range of dissolution rates from mineral particles (Mackey et al. 2015). The media in the reservoirs (not in the culture flasks) were continuously purged with compressed gas throughout the experiment. The headspace of each bubbled reservoir was connected to the headspaces of all 5 associated flasks to maintain constant $\mathrm{pH}$ and dissolved oxygen concentrations. In order to show that the $C$. polykrikoides cells in the experimental treatments were trace metal-limited, L1 trace metals and EDTA were added to the reference flask in each treatment after $16 \mathrm{~d}$ to stimulate C. polykrikoides growth (Fig. S1 in the Supplement). Trace metals and EDTA were not added to the experimental flasks containing sediment. Samples were obtained throughout the experiment by careful airtight siphoning of approximately equal volumes from all flasks.

Since the $\mathrm{pH}$ and dissolved oxygen of overlying water have been shown to impact trace metal release from sediments (Atkinson et al. 2007), and since algal cultures can impact the concentrations of dissolved gases during exponential growth, both $\mathrm{pH}$ and dissolved oxygen were monitored throughout the course of the incubation experiment to ensure that these concentrations remained constant in the growth media. Measurements of $\mathrm{pH}$ on the National Bureau of Standards (NBS) scale were obtained using a bench-top $\mathrm{pH}$ meter calibrated against NBS buffers (Thermo Scientific Orion Star A211) to determine relative differences in $\mathrm{pH}$ among treatments (Table S2 in the Supplement). Dissolved oxygen concentrations were measured using a 4-channel fiberoptic sensor with an external probe for automatic temperature compensation (FireSting; Table S2).

Trace metal samples collected at the start of the experiment (following sediment addition), after $22 \mathrm{~d}$, and after $35 \mathrm{~d}$ of incubation were $0.22 \mu \mathrm{m}$-filtered through ultrapure water-rinsed polyvinylidene fluoride (PVDF) filters with modified acrylic housings using rinsed polypropylene/polyethylene (PP/PE) syringes. Samples were stored in trace metal-clean Teflon fluorinated ethylene propylene (FEP) bottles, immediately acidified (0.024 $\mathrm{M} \mathrm{HCl}$, quartz-distilled), and stored double-bagged (Uline Minigrip) at room temperature for less than a month until trace metal pre-concentration, extraction, and analysis via ICP$\mathrm{MS}$. Dissolved trace metals including $\mathrm{Fe}, \mathrm{Cd}, \mathrm{Ni}, \mathrm{Cu}$, $\mathrm{Zn}, \mathrm{Pb}$, manganese (Mn), and cobalt (Co) were quantified in the trace metal-clean facilities at the NHMFL. Aliquots of the filtered, acidified samples were UVoxidized in the FEP bottles for $1.5 \mathrm{~h}$ to release metals (e.g. $\mathrm{Cu}$ and $\mathrm{Co}$ ) from organic ligands, and subsampled $(5 \mathrm{ml})$ into quartz tubes. Each sample aliquot was spiked with 2 standards: (1) an enriched stable isotope standard $\left({ }^{57} \mathrm{Fe},{ }^{111} \mathrm{Cd},{ }^{62} \mathrm{Ni},{ }^{65} \mathrm{Cu},{ }^{68} \mathrm{Zn}\right.$, and $\left.{ }^{207} \mathrm{~Pb}\right)$ to quantify concentrations by isotope dilution, and (2) a monoisotope standard ( $\mathrm{Mn}$ and $\mathrm{Co}$ ) to quantify concentrations by standard additions (Milne et al. 2010). Trace metals were extracted from the seawater matrix using an automated form of the extraction procedure used by Milne et al. (2010) with a chelating resin column containing Nobias Chelate PA-1 resin as described by Biller \& Bruland (2012). Samples were buffered in-line with ammonium acetate $(0.4 \mathrm{M})$ to $\mathrm{pH}$ 5.5-5.8. Metals were eluted from the column with $0.5 \mathrm{ml}$ of $\mathrm{HNO}_{3}(1.0 \mathrm{M}$, quartz-distilled) at a pre-concentration factor of $\sim 10$. Eluted samples were analyzed along with isotope dilution calibration standards using high-resolution magnetic sector ICP-MS (Thermo ELEMENT 2; Table S3 in the Supplement). Concentrations of dissolved trace metals were determined in experimental treatments and background pure L1 media (Table S3). The rates of change of dissolved trace metals were also determined within each treatment (Table S4 in the Supplement).

Nutrient samples were $0.22 \mu \mathrm{m}$ syringe-filtered and frozen at $-80^{\circ} \mathrm{C}$ until analysis. Concentrations of 
phosphate, nitrate, nitrite, ammonium, and silicate were determined using a modular nutrient analyzer (Seal Analytical AA3 AutoAnalyzer; Table S5 in the Supplement).

In vivo fluorescence was measured using a bench-top fluorometer (Turner Designs Trilogy). Chl a concentrations were calculated using a calibration of in vivo fluorescence and extracted $\mathrm{chl} a$ $\left(\mathrm{R}^{2}=0.999\right.$; JGOFS 1996, Huot \& Babin 2011; Table S6 in the Supplement). Growth responses of $C$. polykrikoides were assessed using chl a concentrations rather than cell counts (e.g. Ebenezer \& Ki 2012) due to the interference of sediment particles in cell count measurements. Chl a concentrations were correlated with cell counts in pooled data from all experimental treatments $\left(R^{2}=0.604\right.$; data not shown). Subsamples of C. polykrikoides culture were preserved in neutral Lugol's iodine solution ( $2 \%$ final concentration) and counted using a bench-top automated particle analysis instrument (FlowCam B3 Series) fitted with a $4 \times$ objective and a $300 \mu \mathrm{m}$ field-of-view flow cell. Growth rates were determined using the exponential growth equation of chl a concentrations over the exponential phase of growth at the last 4 time points from 19 to $35 \mathrm{~d}$ $\left(\mathrm{R}^{2}>0.911\right.$, except at $1200 \mathrm{ppmv}$ where growth was inhibited; Table S7 in the Supplement). Growth rates for reference cultures were determined in the same way. C. polykrikoides cell morphology was examined after $37 \mathrm{~d}$ of incubation using a multiphoton confocal microscope (Nikon A1R MP) at the Herbert Irving Comprehensive Cancer Center at Columbia University. Images were obtained in order to provide a qualitative assessment of the combined effects of $\mathrm{CO}_{2}$ and trace metals on $C$. polykrikoides morphology.

\section{Toxicity bioassay experiment}

C. polykrikoides batch cultures were maintained in a total of $5 \mathrm{Cd}$ treatments and $6 \mathrm{Ni}$ treatments over a range of relevant concentrations based on dissolved trace metal concentrations from the $\mathrm{CO}_{2} /$ sediment incubation experiment. The trace metals $\mathrm{Cd}$ and $\mathrm{Ni}$ were chosen for the bioassays based on temporal trends in the $\mathrm{CO}_{2}$ /sediment incubation experiment. In addition, $\mathrm{Cd}$ has been reported to be toxic to phytoplankton (Brand et al. 1986, Echeveste et al. 2012, Herzi et al. 2013).

One day prior to the start of the experiment, batches of modified L1 media were prepared under a range of total $\mathrm{Ni}$ concentrations (0 to $300 \mathrm{nM}$ ) or $\mathrm{Cd}$ concentrations ( 0 to $3 \mathrm{nM}$ ) by performing serial additions of either nickel(II) sulfate hexahydrate $\left(\mathrm{NiSO}_{4}\right.$. $\left.6 \mathrm{H}_{2} \mathrm{O}\right)$ or cadmium(II) chloride $\left(\mathrm{CdCl}_{2}\right)$ into $100 \mathrm{ml}$ of L1 media in culture flasks. Positive controls were prepared in L1 media with no added $\mathrm{Cd}$ or silicate $(10 \mathrm{nM} \mathrm{Ni}, 0 \mathrm{nM} \mathrm{Cd})$. Also $1 \mathrm{~d}$ prior to the start of the experiment, $C$. polykrikoides cells were centrifuged (300 RCF, 3 min), resuspended, and acclimated in either L1 media with no added Cd or silicate (for the Cd bioassay experiment) or L1 media with no added $\mathrm{Cd}, \mathrm{Ni}$, or silicate (for the $\mathrm{Ni}$ bioassay experiment). At the start of the experiment, aliquots of acclimated $C$. polykrikoides cells were transferred into 3 experimental replicates in each $\mathrm{Cd}$ and $\mathrm{Ni}$ treatment to yield initial cell concentrations of $9.8 \times 10^{3}$ cells l$^{-1}$ in each flask. Cell concentrations were low to allow time for trace metal toxicity responses and to observe growth rates comparable to those in the $\mathrm{CO}_{2}$ /sediment incubation experiment.

Cultures were randomly positioned in the incubator, gently swirled at least once a day, and maintained at ambient $\mathrm{CO}_{2}$ conditions over the course of the $29 \mathrm{~d}$ exposure. Chl a concentrations were obtained as described in the previous subsection and were linearly correlated with cell counts in pooled data from all experimental treatments $\left(R^{2}=0.933\right.$; data not shown). Subcultures for cell counts were preserved as described in the previous subsection and counted using a compound microscope fitted with a 10x objective using a Sedgewick-Rafter counting slide. Growth rates were determined from exponential increases in chl a at the last 4 time points from 10 to $29 \mathrm{~d}$, as described in the previous subsection $\left(R^{2}>0.992\right.$; Table $\mathrm{S} 8$ in the Supplement). Dose-response curves were generated (10 to $300 \mathrm{nM}$ $\mathrm{Ni}$ and 0 to $3 \mathrm{nM} \mathrm{Cd}$ ), and effective concentration values at $50 \%$ and $90 \%$ of the observed maximal growth effects $\left(\mathrm{EC}_{50}\right.$ and $\mathrm{EC}_{90}$, respectively) were calculated based on percent reductions in growth rate relative to the positive control (Table S9 in the Supplement). Note that $\mathrm{EC}_{50}$ and $\mathrm{EC}_{90}$ values were calculated using total added trace metal concentrations (e.g. Ebenezer \& Ki 2012) in media containing EDTA.

Photosynthesis-irradiance (PI) curves were generated during exponential growth after $21 \mathrm{~d}$ under a range of Ni concentrations ( 0 to $300 \mathrm{nM}$ ) or Cd concentrations ( 0 to $3 \mathrm{nM}$ ) using a bench-top Fluorescence Induction and Relaxation (FIRe) system (Gorbunov \& Falkowski 2004) as described by Gorbunov et al. (2001). PI curves were used as physiological assays for $\mathrm{Ni}$ and $\mathrm{Cd}$ since both trace metals have been shown to impact photosystem II (PSII; Sunda 
1989, Boisvert et al. 2007, Perreault et al. 2011). Relative rates of photosynthetic electron transport were calculated according to the following equation, as described by Suggett et al. (2011):

$$
\text { electron transport rate }=I \cdot a_{\mathrm{PSII}} \cdot \phi_{\mathrm{PSII}}
$$

where $I$ is the actinic light intensity, $a_{\mathrm{PSII}}$ is the absorption cross-section of PSII, and $\phi_{\text {PSII }}$ is the quantum efficiency of photochemistry under actinic light. Note that the rates of electron transport were relative measures of photosynthesis since values were not normalized to unit chl $a$ and rates were not measured in units of carbon fixation or oxygen production. The slope of the light-limited portion of the PI curve $(\alpha)$ was determined using a linear regression of the first 5 light levels $\left(\mathrm{R}^{2}>0.972\right.$; Table $\mathrm{S} 10$ in the Supplement). Differences in maximum relative rates of electron transport $\left(\mathrm{P}_{\max } \mu \mathrm{mol}\right.$ electrons $\left.\mathrm{m}^{-2} \mathrm{~s}^{-1}\right)$ were determined using Michaelis-Menten curve-fitting over irradiances of 0 to $600 \mu \mathrm{mol}$ quanta $\mathrm{m}^{-2} \mathrm{~s}^{-1}$ (Ritchie 2008; Table S10).

Free metal ion concentrations of $\mathrm{Cd}$ and $\mathrm{Ni}$ were obtained using Visual MINTEQ software, version 3.1. Input data included $\mathrm{pH}$, temperature, ionic strength (0.701 $\mathrm{M}$ at salinity 34; Pilson 1998), partial pressure of $\mathrm{CO}_{2}$, concentrations of major components of natural seawater at salinity 34, calculated according to Pilson (1998; Table S11 in the Supplement), concentrations of components of media in each treatment (examples in Table S12 in the Supplement), and mean measured dissolved trace metal concentrations $\left(\mathrm{CO}_{2} /\right.$ sediment incubation experiment only).

\section{Statistical analyses}

Data were analyzed using Prism GraphPad software, version 7 . Linear regressions were applied to $\mathrm{pH}$, dissolved oxygen, and dissolved trace metal data to determine significant changes over time. Paired $t$-tests at $95 \%$ confidence were used to analyze macronutrient data to determine significant differences between the initial and final time points. Oneway ANOVA with multiple comparisons and Fisher's least significant difference (LSD) tests were applied to dissolved trace metal, macronutrient, growth rate, and $\alpha$ and $P_{\max }$ data to determine significant differences among treatments. Two-way ANOVA with multiple comparisons and Fisher's LSD tests were applied to $\mathrm{pH}$ and dissolved oxygen data to assess significant differences among treatments at all sampling time points.

\section{RESULTS}

\section{$\mathrm{CO}_{2}$ /sediment incubation experiment}

The trace metal analysis of the size-fractionated sediment used in the incubation experiment indicated that the sediment from Oman contained $0.10 \pm$ $0.01 \mathrm{ppm} \mathrm{Cd}$ and $454 \pm 18 \mathrm{ppm} \mathrm{Ni}$ (mean $\pm \mathrm{SEM}$; Table S1). The sediment was strongly enriched in $\mathrm{Ni}$ and slightly enriched in Co compared to the upper continental crust, but not compared to Oman ophiolite (Table S1).

The measured $\mathrm{pH}$ remained constant in each treatment between 0 and $35 \mathrm{~d}$ (linear regression; Table S2). At all sampling time points, $\mathrm{pH}$ values were significantly different among treatments (2-way ANOVA, $\mathrm{p}<0.001$; Table S2). The measured $\mathrm{pH}_{\mathrm{NBS}}$ values at 400, 800, and 1200 ppmv $\mathrm{CO}_{2}$ were $8.13 \pm 0.01,7.89 \pm$ 0.01 , and $7.74 \pm 0.01$, respectively (mean \pm SEM). Dissolved oxygen concentrations remained constant in each treatment between 0 and $35 \mathrm{~d}$ (linear regression; Table S2). Dissolved oxygen concentrations were not significantly different among treatments at all sampling time points (2-way ANOVA; Table S2).

Dissolved Fe concentrations significantly increased over time at $1200 \mathrm{ppmv} \mathrm{CO}_{2}$ (linear regression, $\mathrm{p}=$ 0.0017; Table S4). After $35 \mathrm{~d}$, concentrations were significantly elevated at $1200 \mathrm{ppmv} \mathrm{CO}_{2}$ compared to 400 ppmv (1-way ANOVA, p = 0.0086; Fig. 1) and 800 ppmv $\mathrm{CO}_{2}(\mathrm{p}=0.0060)$. Concentrations were significantly different from background media after $35 \mathrm{~d}$ at 1200 ppmv $\mathrm{CO}_{2}$ (1-way ANOVA, $\mathrm{p}=0.0007$; Table S3). Dissolved Cd concentrations increased

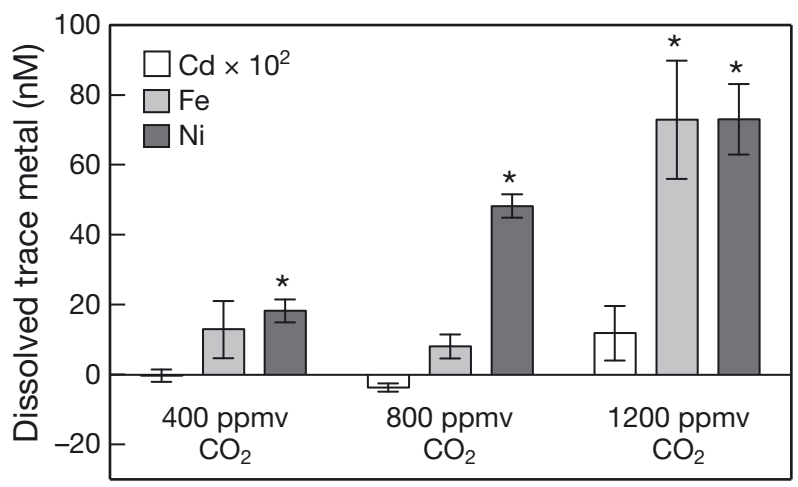

Fig. 1. Concentrations of dissolved trace metals due to mobilization from sediment after $35 \mathrm{~d}$ in Cochlodinium polykrikoides growth media at 400, 800, and $1200 \mathrm{ppmv} \mathrm{CO}_{2}$ (mean $\pm \mathrm{SEM} ; \mathrm{n}=3$ for all treatments), calculated from differences between total measured dissolved trace metals in experimental treatments and in background L1 media. * Significant compared to the other treatments (pairwise comparisons of 1-way ANOVA, $\mathrm{p}<0.05$ ) 
over time between 0 and $35 \mathrm{~d}$ at 1200 ppmv $\mathrm{CO}_{2}$ relative to the other treatments, but the trend was not significant (linear regression; Table S4). Cd concentrations were not significantly different among $\mathrm{CO}_{2}$ treatments after 35 d (1-way ANOVA; Fig. 1). Concentrations of dissolved $\mathrm{Cd}$ were not significantly different from the background media (1-way ANOVA; Table S3). Dissolved Ni concentrations increased over time at 400 ppmv (linear regression, $\mathrm{p}=0.0014$; Table S4), 800 ppmv ( $\mathrm{p}<0.001)$, and $1200 \mathrm{ppmv} \mathrm{CO}_{2}$ $(p=0.0008)$. After $35 \mathrm{~d}$, Ni concentrations were significantly higher at $1200 \mathrm{ppmv} \mathrm{CO}_{2}$ compared to 400 ppmv (1-way ANOVA, p = 0.0009; Fig. 1) and 800 ppmv $\mathrm{CO}_{2}(\mathrm{p}=0.0334)$. Concentrations were significantly different from background media after $22 \mathrm{~d}$ in all $\mathrm{CO}_{2}$ treatments (1-way ANOVA, $\mathrm{p}<0.001$; Table S3) and after $35 \mathrm{~d}$ in all treatments ( $<<0.05)$.

Dissolved Mn concentrations increased over time at 400 ppmv (linear regression, $\mathrm{p}<0.001$; Table S4), 800 ppmv ( $\mathrm{p}=0.0040)$, and 1200 ppmv $\mathrm{CO}_{2}(\mathrm{p}<$ $0.001)$. However, Mn concentrations were not significantly different among treatments after $35 \mathrm{~d}$ (1-way ANOVA; Table S3). Mn concentrations were significantly different from background media after $35 \mathrm{~d}$ in all $\mathrm{CO}_{2}$ treatments (1-way ANOVA, $\mathrm{p}<0.001$; Table S3). Dissolved Co concentrations did not increase over time (linear regression; Table S4). After $35 \mathrm{~d}$, Co concentrations were significantly higher at 1200 ppmv $\mathrm{CO}_{2}$ compared to 400 ppmv (1-way ANOVA, $\mathrm{p}=0.0419$; Table S3) and 800 ppmv $\mathrm{CO}_{2}$ $(p=0.0385)$. Co concentrations were significantly different from background media after $35 \mathrm{~d}$ at $400 \mathrm{ppmv}$ (1-way ANOVA, $\mathrm{p}=0.0064$; Table S3) and $800 \mathrm{ppmv}$ $(p=0.0059)$, but not at 1200 ppmv $\mathrm{CO}_{2}$. Dissolved $\mathrm{Cu}, \mathrm{Zn}$, and $\mathrm{Pb}$ concentrations did not increase over time (linear regression; Table S4) and were not significantly different among treatments after $35 \mathrm{~d}$ (1way ANOVA; Table S3). Cu concentrations were significantly different from background media after $35 \mathrm{~d}$ at 800 ppmv $\mathrm{CO}_{2}$ (1-way ANOVA, p $=0.0362$; Table S3), but not at 400 or 1200 ppmv $\mathrm{CO}_{2}$. $\mathrm{Zn}$ and $\mathrm{Pb}$ concentrations were not significantly different from background media after 35 d (1-way ANOVA; Table S3). Zn concentrations were especially high relative to those in surface seawater (Sunda 1994).

Nitrate, nitrite, and silicate concentrations were not significantly different between the initial and final time points in all $\mathrm{CO}_{2}$ treatments (paired $t$-test; Table S5). Ammonium concentrations increased over time at 400 and $800 \mathrm{ppmv} \mathrm{CO}_{2}$ (linear regression, $\mathrm{p}=$ 0.0025 and $\mathrm{p}=0.0439$, respectively; Table S5), but not at $1200 \mathrm{ppmv} \mathrm{CO}_{2}$. It is possible that ammonium concentrations increased in the culture flasks at 400 and 800 ppmv $\mathrm{CO}_{2}$ as a result of metabolic waste production. Ammonium concentrations also increased in the media containing sediment without culture (data not shown), suggesting a possible abiotic effect from sediment. Phosphate concentrations decreased over time at 800 ppmv $\mathrm{CO}_{2}$ (linear regression, $\mathrm{p}=0.0294$; Table S5), but not at 400 or 1200 ppmv $\mathrm{CO}_{2}$. Phosphate, ammonium, nitrite, and silicate concentrations were not significantly different among treatments after 35 d (1-way ANOVA; Table S5). Nitrate concentrations were significantly different at 800 and 1200 ppmv $\mathrm{CO}_{2}$ (1-way ANOVA, p = 0.0452; Table S5). Macronutrient concentrations were high enough to not be limiting during exponential growth.

Based on chl a concentrations in experimental replicates, cell biomass decreased at high suspended sediment concentrations at elevated $\mathrm{CO}_{2}$ (Fig. 2). Growth rates calculated from the exponential increases in chl a concentrations significantly decreased at 1200 ppmv $\mathrm{CO}_{2}$ compared to 400 ppmv (1-way ANOVA, $\mathrm{p}=0.0048$; Fig. 3 ) and 800 ppmv $\mathrm{CO}_{2}(\mathrm{p}=$ $0.0207)$. Growth rates in the reference flask in all treatments exceeded $0.2 \mathrm{~d}^{-1}$ over the same time period (Table S7). Confocal microscopy images obtained at the end of the incubation experiment indicated decreased cell size and autofluorescence of Cochlodinium polykrikoides cells following sediment additions at 1200 ppmv compared to 800 ppmv $\mathrm{CO}_{2}$ (Fig. 4).

\section{Toxicity bioassay experiment}

C. polykrikoides growth rates in all $\mathrm{Cd}$ and $\mathrm{Ni}$ bioassay treatments were significantly decreased compared to the positive control (1-way ANOVA, p <

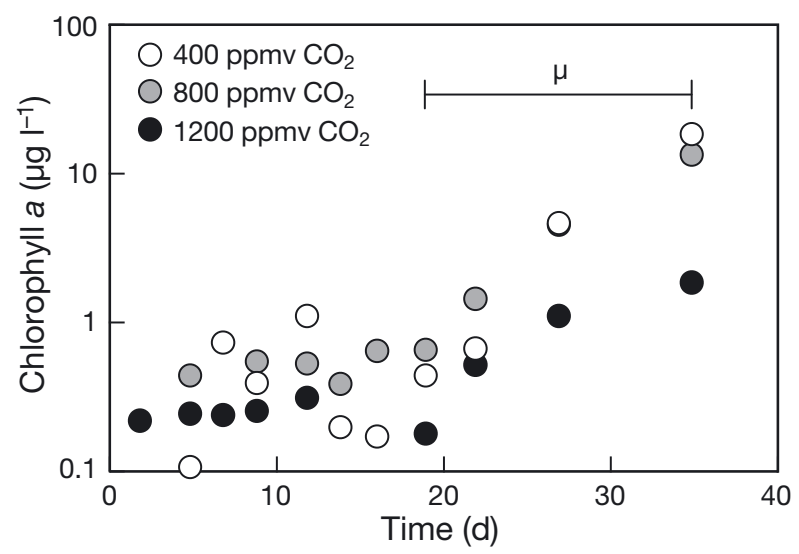

Fig. 2. Representative Cochlodinium polykrikoides growth curves from one of the replicates in each treatment following sediment additions at 400, 800, and 1200 ppmv $\mathrm{CO}_{2}$. Bar labeled ' $\mu$ ' indicates time interval over which growth rates were calculated 


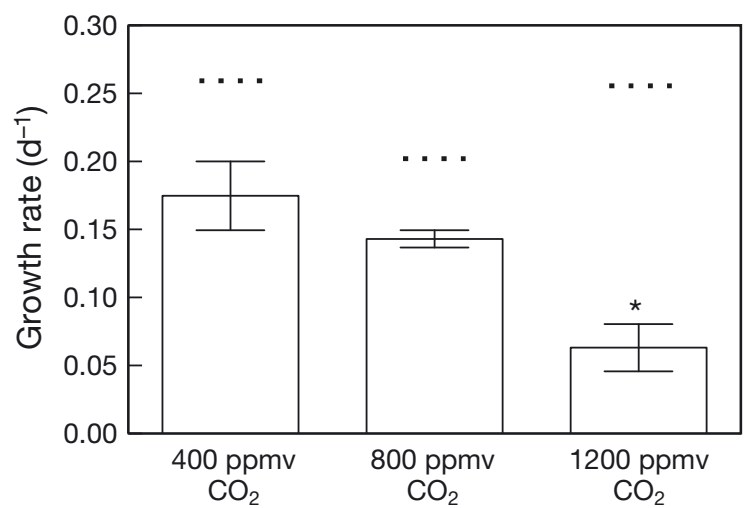

Fig. 3. Cochlodinium polykrikoides growth rates in media with high suspended sediment concentrations at 400, 800, and 1200 ppmv $\mathrm{CO}_{2}$ (mean $\pm \mathrm{SEM}_{\mathrm{n}} \mathrm{n}=3$ for all treatments), calculated from exponential increases in chl a between 19 and $35 \mathrm{~d}$. ${ }^{*}$ Significant compared to the other treatments $(1$-way ANOVA, $\mathrm{p}<0.05)$. Dotted lines indicate growth rate in the reference flask (culture without sediment) in each treatment
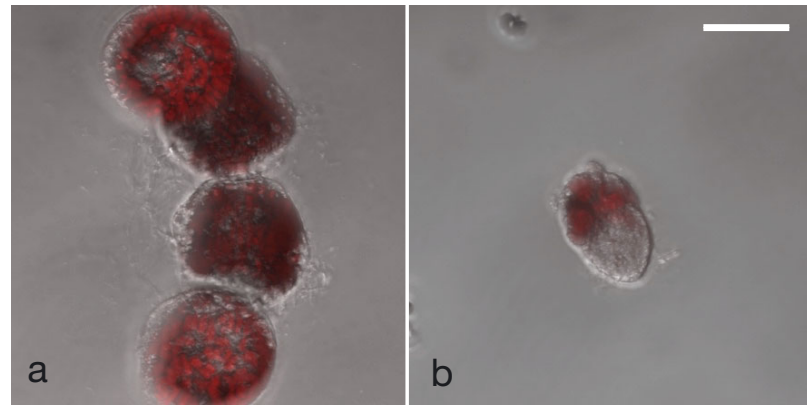

Fig. 4. Confocal microscopy images of representative Cochlodinium polykrikoides cells after $37 \mathrm{~d}$ in media with high suspended sediment concentrations at (a) 800 and (b) 1200 ppmv $\mathrm{CO}_{2}$. Scale bar $=25 \mu \mathrm{m}$

0.05; Fig. 5a). Dose-response curves based on mean percent reductions in growth rate relative to the positive control indicated dose-dependent, sigmoidal responses of $C$. polykrikoides growth to both $\mathrm{Cd}$ and $\mathrm{Ni}$ (Fig. 5b). Note that the toxicity responses represent the effects of added total trace metals in the presence of EDTA to the base seawater media. $\mathrm{EC}_{50}$ and $\mathrm{EC}_{90}$ were determined using the dose-response curves (Table 1).

PI curves obtained after $21 \mathrm{~d}$ during exponential growth were used to calculate relative differences in $\alpha$ and $P_{\max }$ parameters for $\mathrm{Cd}$ and Ni (Fig. 6). In the $\mathrm{Ni}$ experiment, $\alpha$ parameters in all experimental treatments were not significantly different from those in the $0 \mathrm{nM} \mathrm{Ni}$ treatment, with the exception of $60 \mathrm{nM}$ Ni (1-way ANOVA, $\mathrm{p}=0.0262$; Table S10). $\mathrm{P}_{\max }$ parameters in all treatments were significantly different from those in the $0 \mathrm{nM}$ Ni treatment (1-way ANOVA, $\mathrm{p}<0.01$; Table S10). In the Cd experiment,
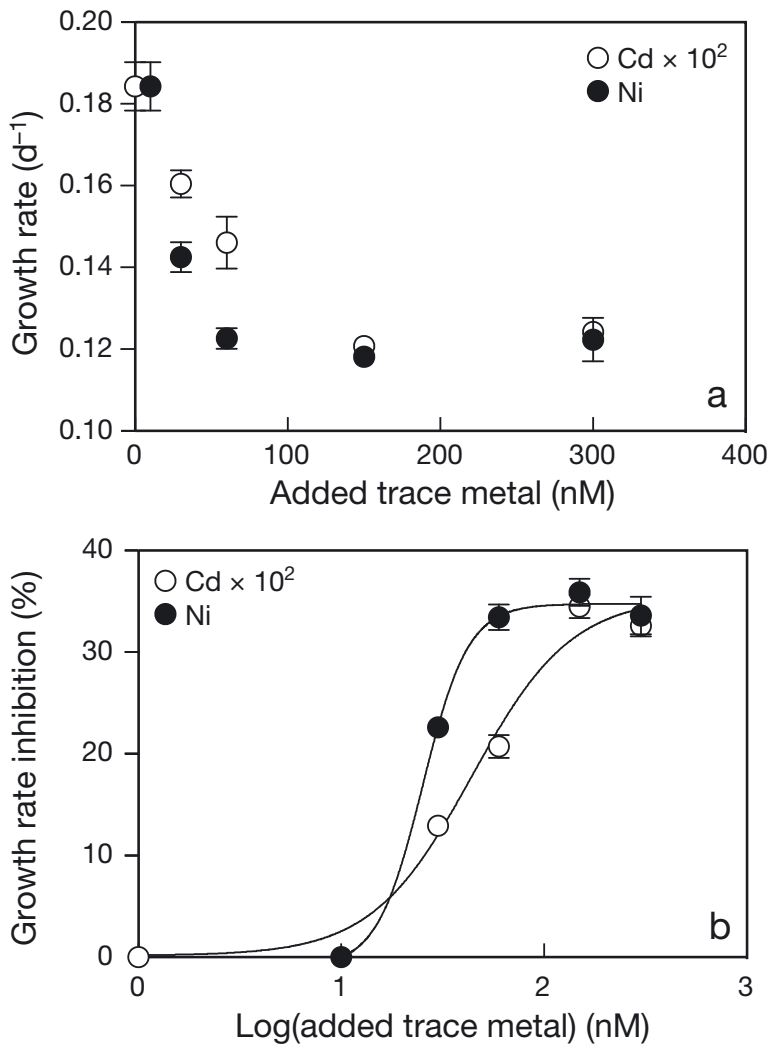

Fig. 5. Cochlodinium polykrikoides growth response curves at ambient $\mathrm{CO}_{2}$ under a range of total $\mathrm{Cd}$ or Ni concentrations (without sediment). (a) Growth rates as a function of added total trace metals (mean $\pm \mathrm{SEM}_{i} \mathrm{n}=3$ for all treatments), based on exponential increases in chl a between 10 and 29 d. (b) Dose-response curves (mean \pm SEM; $\mathrm{n}=3$ for all treatments), based on percent reductions in growth rate relative to the positive control

$\alpha$ and $P_{\max }$ parameters in all experimental treatments were significantly different from those in the $0 \mathrm{nM}$ Cd treatment (1-way ANOVA, $\mathrm{p}<0.01$; Table S10). The PI curves for $\mathrm{Cd}$ and $\mathrm{Ni}$ indicated decreased overall photosynthetic capacity at high $\mathrm{Cd}$ and $\mathrm{Ni}$ concentrations.

Based on the comparison of mean free metal ion concentrations in the $\mathrm{CO}_{2}$ /sediment incubation experiment and the toxicity bioassay experiment (Table 2), the calculated $\mathrm{Ni}^{2+}$ concentrations were lower in the Ni bioassay experiment due to complex-

Table 1. Effective concentration values at $50 \%$ and $90 \%$ of the observed maximal Cochlodinium polykrikoides growth $\left(\mathrm{EC}_{50}\right.$ and $\mathrm{EC}_{90}$; mean $\pm \mathrm{SEM} ; \mathrm{n}=3$ for all treatments $)$ derived from the $\mathrm{Cd}$ and $\mathrm{Ni}$ dose-response curves

\begin{tabular}{|lll|}
\hline Trace metal & $\mathrm{EC}_{50}(\mathrm{nM})$ & $\mathrm{EC}_{90}(\mathrm{nM})$ \\
\hline $\mathrm{Cd}$ & $0.44 \pm 0.01$ & $1.53 \pm 0.01$ \\
$\mathrm{Ni}$ & $25.3 \pm 1.1$ & $44.6 \pm 1.2$ \\
\hline
\end{tabular}




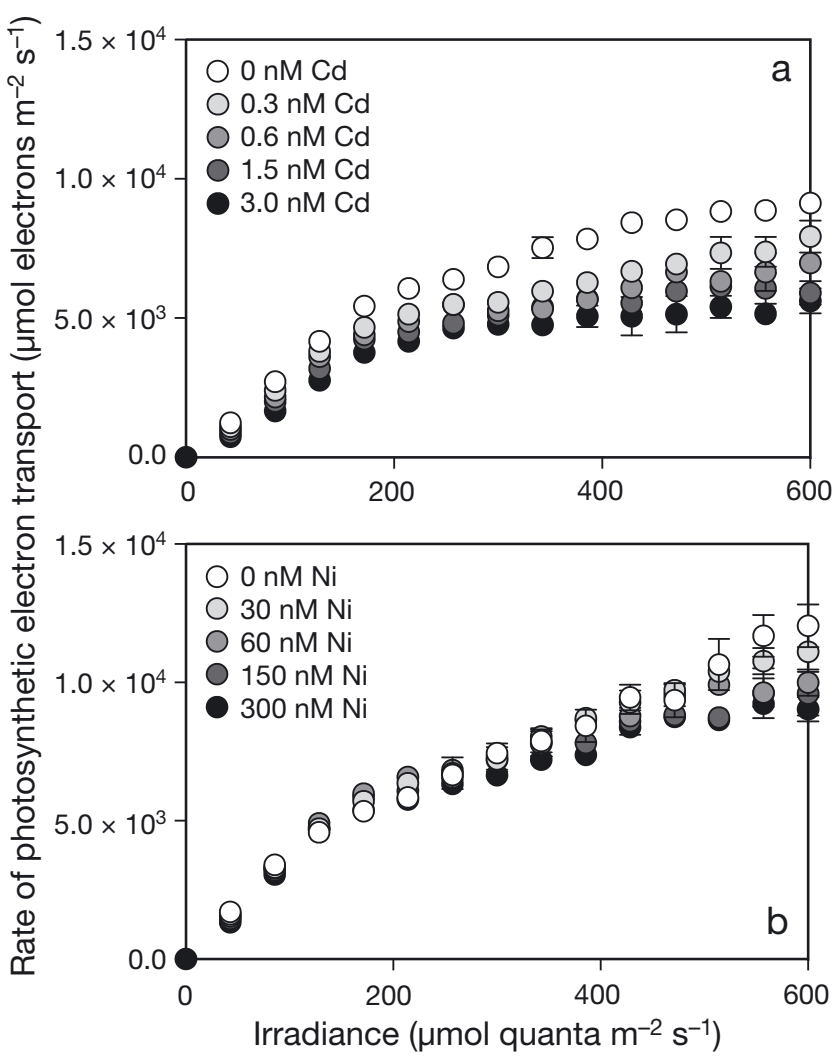

Fig. 6. Photosynthesis-irradiance curves obtained after $21 \mathrm{~d}$ during exponential growth of Cochlodinium polykrikoides at ambient $\mathrm{CO}_{2}$ under a range of total added (a) $\mathrm{Cd}$ or (b) $\mathrm{Ni}$ concentrations (without sediment; mean $\pm \mathrm{SEM}_{i} \mathrm{n}=3$ for all treatments)

ation with EDTA. The mean background-corrected $\mathrm{Ni}^{2+}$ concentration at $1200 \mathrm{ppm}$ after $35 \mathrm{~d}$ of incubation in the $\mathrm{CO}_{2}$ /sediment experiment $(54.8 \mathrm{nM}$; Table 2) was orders of magnitude higher than the mean $\mathrm{Ni}^{2+}$ concentration in the $300 \mathrm{nM}$ Ni bioassay treatment $(0.13 \mathrm{nM})$. The calculated $\mathrm{Cd}^{2+}$ concentrations in the $\mathrm{CO}_{2}$ /sediment incubation experiment were within the range of the concentrations tested in the Cd bioassay experiment (Table 2). The mean background-corrected $\mathrm{Cd}^{2+}$ concentration at $1200 \mathrm{ppm}$ after 22 and $35 \mathrm{~d}$ in the $\mathrm{CO}_{2} /$ sediment experiment (0.003 $\mathrm{nM}_{i}$ Table 2) was similar to the mean added $\mathrm{Cd}^{2+}$ concentration in the $0.3 \mathrm{nM} \mathrm{Cd}$ bioassay treatment $(0.005 \mathrm{nM})$.

\section{DISCUSSION}

This is the first investigation of the toxic, synergistic effects of trace metals mobilized from suspended sediments and high $\mathrm{CO}_{2}$ on phytoplankton growth rates and photosynthesis. This study fulfilled the objectives and addressed the research needs: (1) to
Table 2. Mean total Cd and Ni concentrations and calculated free $\mathrm{Cd}^{2+}$ and $\mathrm{Ni}^{2+}$ concentrations for all experimental treatments in the $\mathrm{CO}_{2}$ /sediment incubation experiment, calculated from differences between trace metals in experimental treatments and in background L1 media, and in the toxicity bioassay experiments under a range of $\mathrm{Cd}$ or Ni. Free metal ion concentrations (determined using Visual MINTEQ) in the $\mathrm{CO}_{2}$ /sediment experiment were calculated using measured dissolved trace metals (Table S3 in the Supplement), while those in the toxicity bioassay experiments were calculated using the amounts of trace metals added. $\mathrm{Ni}^{2+}$ concentrations in the $\mathrm{Cd}$ toxicity bioassay were identical because total added $\mathrm{Ni}$ was constant $(10 \mathrm{nM})$. $\mathrm{Cd}^{2+}$ values in the Ni toxicity bioassay were consistently low because no $\mathrm{Cd}$ was added

\begin{tabular}{|c|c|c|c|c|}
\hline Treatment & $\mathrm{Cd}(\mathrm{nM})$ & $\mathrm{Cd}^{2+}(\mathrm{nM})$ & $\mathrm{Ni}(\mathrm{nM})$ & $\mathrm{Ni}^{2+}(\mathrm{nM})$ \\
\hline \multicolumn{5}{|c|}{400 ppmv $\mathrm{CO}_{2}$ (with sediment) } \\
\hline $0 \mathrm{~d}$ & 0.0 & $-9.0 \times 10^{-6}$ & 0.2 & -0.3 \\
\hline $22 \mathrm{~d}$ & 0.0 & $-9.0 \times 10^{-6}$ & 16.9 & 12.0 \\
\hline $35 \mathrm{~d}$ & 0.0 & $-9.0 \times 10^{-6}$ & 18.4 & 13.1 \\
\hline \multicolumn{5}{|c|}{800 ppmv $\mathrm{CO}_{2}$ (with sediment) } \\
\hline $0 \mathrm{~d}$ & 0.0 & $4.0 \times 10^{-6}$ & 3.3 & 2.4 \\
\hline $22 \mathrm{~d}$ & 0.0 & $4.0 \times 10^{-6}$ & 37.7 & 28.0 \\
\hline $35 \mathrm{~d}$ & 0.0 & $4.0 \times 10^{-6}$ & 48.4 & 35.9 \\
\hline \multicolumn{5}{|c|}{$1200 \mathrm{ppmv}^{\mathrm{CO}} \mathrm{O}_{2}$ (with sediment) } \\
\hline $0 \mathrm{~d}$ & 0.0 & $9.0 \times 10^{-6}$ & 7.3 & 5.6 \\
\hline $22 \mathrm{~d}$ & 0.1 & $3.4 \times 10^{-3}$ & 68.9 & 51.6 \\
\hline $35 \mathrm{~d}$ & 0.1 & $3.4 \times 10^{-3}$ & 73.2 & 54.8 \\
\hline \multicolumn{5}{|c|}{ Cd toxicity bioassay (without sediment) } \\
\hline $0 \mathrm{nM} \mathrm{Cd}$ & 0.0 & $1.7 \times 10^{-9}$ & 10.0 & $3.4 \times 10^{-3}$ \\
\hline $0.3 \mathrm{nM} \mathrm{Cd}$ & 0.3 & $5.2 \times 10^{-3}$ & 10.0 & $3.4 \times 10^{-3}$ \\
\hline $0.6 \mathrm{nM} \mathrm{Cd}$ & 0.6 & $1.0 \times 10^{-2}$ & 10.0 & $3.4 \times 10^{-3}$ \\
\hline $1.5 \mathrm{nM} \mathrm{Cd}$ & 1.5 & $2.6 \times 10^{-2}$ & 10.0 & $3.4 \times 10^{-3}$ \\
\hline $3.0 \mathrm{nM} \mathrm{Cd}$ & 3.0 & $5.2 \times 10^{-2}$ & 10.0 & $3.4 \times 10^{-3}$ \\
\hline \multicolumn{5}{|c|}{ Ni toxicity bioassay (without sediment) } \\
\hline $0 \mathrm{nM} \mathrm{Ni}$ & 0.0 & $1.7 \times 10^{-9}$ & 0.0 & $3.3 \times 10^{-11}$ \\
\hline $10 \mathrm{nM} \mathrm{Ni}$ & 0.0 & $1.7 \times 10^{-9}$ & 10.0 & $3.4 \times 10^{-3}$ \\
\hline $30 \mathrm{nM} \mathrm{Ni}$ & 0.0 & $1.7 \times 10^{-9}$ & 30.0 & $1.0 \times 10^{-2}$ \\
\hline $60 \mathrm{nM} \mathrm{Ni}$ & 0.0 & $1.8 \times 10^{-9}$ & 60.0 & $2.1 \times 10^{-2}$ \\
\hline $150 \mathrm{nM} \mathrm{Ni}$ & 0.0 & $1.8 \times 10^{-9}$ & 150.0 & $5.8 \times 10^{-2}$ \\
\hline $300 \mathrm{nM} \mathrm{Ni}$ & 0.0 & $1.9 \times 10^{-9}$ & 300.0 & $1.3 \times 10^{-1}$ \\
\hline
\end{tabular}

elucidate the effects of specific components of mineral particles on individual phytoplankton species, consistent with recommendations from Paytan et al. (2009), (2) to examine the biological responses to multiple environmental factors including ocean acidification, consistent with recommendations from Doney et al. (2009) and Hoffmann et al. (2012), and (3) to determine the implications of ocean acidification on noncalcifying marine organisms, consistent with recommendations from Connell \& Russell (2010).

Results of the $\mathrm{CO}_{2} /$ sediment incubation experiment support Hypothesis 1 (see the 'Introduction') that lithogenic trace metal concentrations would increase under increasing $\mathrm{CO}_{2}$. In this study, high 
$\mathrm{CO}_{2}$ (low pH) conditions increased the concentrations of dissolved $\mathrm{Fe}$ and $\mathrm{Ni}$ due to mobilization from sediments (Fig. 1; Tables S3 \& S4). Increasing dissolved trace metal concentrations over time at 1200 ppmv $\mathrm{CO}_{2}$ likely resulted from increased leaching from sediment, e.g. as a result of increased solubility (Millero et al. 2009) or increased total free metal concentrations (Millero et al. 2009, Xu et al. 2012). The increasing total dissolved Fe concentrations at high $\mathrm{CO}_{2}$ may have been driven by increased free Fe(II) concentrations (Millero et al. 2009) combined with decreased Fe uptake due to growth inhibition or decreased bioavailability (Shi et al. 2010). It is important to note that adsorption of Fe on the walls of the culture bottles could have also affected the concentrations of dissolved $\mathrm{Fe}$ over the course of the incubation experiment (Fischer et al. 2007).

Dissolved $\mathrm{Cd}$ concentrations increased at high $\mathrm{CO}_{2}$ (Fig. 1; Tables S3 \& S4), but the trend was not significant, likely because most of the $\mathrm{Cd}$ signal originated from the seawater media base. Calculated free $\mathrm{Cd}^{2+}$ concentrations also increased with $\mathrm{CO}_{2}$ (Table 2).

Increasing $\mathrm{Ni}$ concentrations at high $\mathrm{CO}_{2}$ (Fig. 1; Tables S3 \& S4) were likely caused by increased free metal concentrations leaching from the sediment, assuming that natural complexing agents were present in the L1 media (Millero et al. 2009, Xu et al. 2012). Calculated free $\mathrm{Ni}^{2+}$ concentrations increased both as a function of time and $\mathrm{CO}_{2}$ concentration (Table 2). The sediment used in this study was highly enriched in $\mathrm{Ni}$ content relative to average crustal abundance (Table $\mathrm{S} 1$ ), so it is possible that this sediment had relatively high $\mathrm{Ni}$ solubility and/or bioavailability. However, the solubility and bioavailability of Ni from the Oman sediment are not known.

Although the sediment was also enriched in $\mathrm{Co}$, dissolved Co concentrations did not increase over time in the incubation experiment (Table S3). It has been shown that dissolved Co is intensely complexed in seawater (Baars \& Croot 2015), but it is not known how or to what extent dissolved Co concentrations will change with ocean acidification.

Growth responses in this study indicated that Cochlodinium polykrikoides experienced increased lithogenic trace metal toxicity under increasing $\mathrm{CO}_{2}$ conditions. Sediment inputs together with high $\mathrm{CO}_{2}$ significantly decreased growth rates (Fig. 3). Confocal microscopy images qualitatively illustrated the combined impacts of lithogenic trace metals and $\mathrm{CO}_{2}$ on cell morphology (Fig. 4). The inhibition of $C$. polykrikoides growth at high $\mathrm{CO}_{2}$ was not the result of increased $\mathrm{CO}_{2}$ (decreased $\mathrm{pH}$ ) alone, since the growth rate in the reference flask (culture, no sediment) at 1200 ppmv $\mathrm{CO}_{2}$ was similar to that in the reference flasks at 400 and 800 ppmv $\mathrm{CO}_{2}$ (all $>0.2 \mathrm{~d}^{-1}$; Fig. 3). The biological response was not caused by the sediment alone, since $C$. polykrikoides growth rates were significantly higher following sediment additions at 400 and 800 ppmv compared to 1200 ppmv $\mathrm{CO}_{2}$ (Fig. 3). Decreased growth rates were not caused by changes in dissolved oxygen, $\mathrm{pH}$, or macronutrient concentrations over the $35 \mathrm{~d}$ incubation period (Tables S2 \& S5). There were no significant reductions in individual nutrient concentrations or changes in stoichiometric ratios in the C. polykrikoides culture media (Table S5).

Results of the toxicity bioassay experiment support Hypothesis 2 (see the 'Introduction') that increased concentrations of trace metals mobilized from sediments would negatively affect the growth of $C$. polykrikoides. Growth rates significantly decreased under increasing $\mathrm{Cd}$ or $\mathrm{Ni}$ concentrations (Fig. 5a). In addition, the biological responses of C. polykrikoides to $\mathrm{Cd}$ and $\mathrm{Ni}$ were dose-dependent (Fig. 5b). Based on the PI curves from this study (Fig. 6), it is possible that high concentrations of both $\mathrm{Cd}$ and $\mathrm{Ni}$ impacted photosynthetic electron transport from PSII. Ni has been shown to cause conformational changes in the oxygen-evolving complex of PSII and inhibit electron transport activity (Boisvert et al. 2007). Cd has been shown to act on several inhibitory sites (on the donor and acceptor side of PSII) and also decrease rates of electron transport (Perreault et al. 2011). However, it is also possible that $\mathrm{Cd}$ and/or Ni inhibited growth and decreased photosynthetic electron transport rates via another toxicity mechanism (Sunda 1994).

Determining the cause of the toxicity response in the $\mathrm{CO}_{2}$ /sediment incubation experiment is not straightforward. Many predictions of trace metal bioavailability assume that the concentration of the free metal ion drives uptake and toxicity (Sunda \& Huntsman 1998, Domingos et al. 2015). Therefore, free metal $\mathrm{Cd}$ and $\mathrm{Ni}$ concentrations were compared in the $\mathrm{CO}_{2}$ /sediment incubation experiment and the $\mathrm{Cd}$ and Ni toxicity bioassay experiments (Table 2). In the bioassay experiments, toxic effects were observed at very low $\mathrm{Cd}^{2+}$ and $\mathrm{Ni}^{2+}$ concentrations, indicating that $C$. polykrikoides was sensitive to both free $\mathrm{Cd}$ and Ni (Table 2). However, the concentrations of $\mathrm{Ni}^{2+}$ were lower in the bioassay compared to the $\mathrm{CO}_{2}$ /sediment experiment as a result of complexation (Table 2). It is therefore possible that: (1) total $\mathrm{Ni}$ rather than free $\mathrm{Ni}$ concentrations explained the toxic effect at high $\mathrm{CO}_{2}$, or (2) there was an additive or synergistic effect of free $\mathrm{Ni}$ with another factor (e.g. free $\mathrm{Cd}, \mathrm{Zn}$, or $\mathrm{Cu}$ ) at high $\mathrm{CO}_{2}$. 
Concentrations of total dissolved $\mathrm{Zn}$ and $\mathrm{Cu}$ were high relative to surface seawater (Sunda 1994, Morel \& Price 2003; Table S3). The average concentrations of free $\mathrm{Zn}^{2+}$ and $\mathrm{Cu}^{2+}$ calculated at $1200 \mathrm{ppmv} \mathrm{CO}_{2}$ after $35 \mathrm{~d}$ (141 nM and $3.6 \mathrm{nM}$, respectively; data not shown) were within the ranges shown to be toxic to marine phytoplankton (Brand et al. 1986, Sunda 1994, Miao et al. 2005). Although $\mathrm{Zn}$ and $\mathrm{Cu}$ did not exhibit significant temporal or $\mathrm{CO}_{2}$-dependent trends (Table S4), it is possible that either $\mathrm{Zn}$ or $\mathrm{Cu}$ contributed to the increasing toxicity of suspended sediments at high $\mathrm{CO}_{2}$.

It is also possible that the calculated $\mathrm{Ni}^{2+}$ in the $\mathrm{CO}_{2}$ /sediment incubation experiment was overestimated due to complexation by a ligand or an agent not represented in the Visual MINTEQ speciation calculation. The extent of complexation of trace metals to ligands (e.g. biotic ligands, inorganic species) or particles (e.g. humic substances, iron manganese oxides, clays) can significantly impact their bioavailability and toxicity (Sunda \& Huntsman 1998, Meyer et al. 1999, Domingos et al. 2015). Ligand composition was not measured in this study, but it is possible that the sediment or the organism itself altered the composition of metal-chelating agents in the media and caused free Ni to become complexed (Sunda \& Huntsman 1998, Sunda et al. 2005).

Several studies have shown that free metal ion concentrations do not always best predict toxicity responses in the presence of biotic ligands (e.g. Meyer et al. 1999, De Schamphelaere et al. 2005). For example, external cellular $\mathrm{Cu}$ (the concentration of $\mathrm{Cu}$ removed from algae by adding EDTA) better predicted the toxicity responses of freshwater green algae under a range of $\mathrm{pH}$ than free $\mathrm{Cu}^{2+}$ (De Schamphelaere et al. 2005). It is possible that the modeled free ion concentrations were not the best predictors of toxicity in the $\mathrm{CO}_{2}$ /sediment incubation experiment.

If, instead, total dissolved $\mathrm{Cd}$ and $\mathrm{Ni}$ concentrations adequately predicted the toxicity responses of $C$. polykrikoides in this study, total Cd likely did not cause the toxicity response in the $\mathrm{CO}_{2} /$ sediment incubation experiment since most of the $\mathrm{Cd}$ signal originated from the seawater media base. Doseresponses were, however, consistent with Ni toxicity in the $\mathrm{CO}_{2}$ /sediment incubation experiment. Although the toxicity of total Ni likely increased at high $\mathrm{CO}_{2}$, there may have been some other factor(s) contributing to toxicity. It is possible that the presence of some other undetected trace metal(s) or chemical(s) present in the sediment and/or some additive or synergistic effect (e.g. from the relatively high dissolved
Zn or $\mathrm{Cu}$ concentrations) could have contributed to the toxic response at high $\mathrm{CO}_{2}$.

Additional experiments are required to better understand the combined effects of $\mathrm{CO}_{2}$ and suspended sediments on the growth of phytoplankton. In particular, the interactive toxic effects of specific components of sediment (e.g. different free metals) need to be characterized. Additionally, the impacts of ocean acidification on metal complexing agents need to be examined (Millero et al. 2009, Xu et al. 2012). Finally, the combined effects of suspended sediments and ocean acidification in other regions of the world need to be assessed using other phytoplankton species and different sediment sources. Toxicity responses to trace metals dissolved from sediments likely vary significantly depending on phytoplankton species and sediment composition (Brand et al. 1986, Paytan et al. 2009, Mackey et al. 2012). Such studies would improve understanding of the complex impacts of ocean acidification on marine biogeochemical dynamics.

The experimental results presented here indicate that high suspended sediment concentrations could deliver potentially toxic concentrations of trace elements (e.g. total Ni) to coastal marine ecosystems such as the Persian Gulf over the course of this century. The results strongly suggest that beyond a certain threshold, a combination of increased $\mathrm{CO}_{2}$ (decreased $\mathrm{pH}$ ) together with elevated suspended sediment concentrations could significantly decrease growth rates and photosynthesis of marine phytoplankton, as shown in the case of C. polykrikoides. Under moderate $\mathrm{CO}_{2}$ conditions, sediments may not be inhibitory to $C$. polykrikoides growth. Growth rates may decrease significantly at high $\mathrm{CO}_{2}$ and high dissolved $\mathrm{Ni}$ concentrations; however, some other factor(s) present in sediments could also contribute to the biological response. These results may help improve predictions of ecosystem-biogeochemical models over the course of this century.

Acknowledgements. We thank Andrew Juhl and Hugh Ducklow for thoughtful comments, insights, and advice; William Landing and Maxim Gorbunov for logistical support; Tegan Gallina, Palita Tong, and Martin Fleisher for laboratory assistance; Theresa Swayne and Cedric Espenel at the Herbert Irving Comprehensive Cancer Center at Columbia University for assistance with confocal microscopy; and 3 anonymous reviewers for constructive comments on the manuscript. This work was partly supported by NASA Headquarters under the NASA Earth and Space Science Fellowship Program grants 13-EARTH13F-0131 and 14-EARTH14R-0001. Funding at the National High Magnetic Field Laboratory was provided by the National Science Foundation Cooperative Agreement DMR-1157490, 
the State of Florida, and the US Department of Energy. This is Lamont-Doherty Earth Observatory Contribution \#8143. The authors do not declare any conflicts of interest.

\section{LITERATURE CITED}

Al-Azri AR, Piontkovski SA, Al-Hashmi KA, Goes JI, Gomes HR, Glibert PM (2014) Mesoscale and nutrient conditions associated with the massive 2008 Cochlodinium polykrikoides bloom in the Sea of Oman/Arabian Gulf. Estuar Coasts 37:325-338

Al Gheilani HM, Matsuoka K, AlKindi AY, Amer S, Waring C (2011) Fish kill incidents and harmful algal blooms in Omani waters. Agric Mar Sci 16:23-33

Al-Yamani F (2008) Importance of the freshwater influx from the Shatt al-Arab River on the Gulf marine environment. In: Abuzinada AH, Barth HJ, Krupp F, Böer B, Al Abdessalaam TZ (eds) Protecting the Gulf's marine ecosystems from pollution. Birkhäuser Verlag, Basel, p 207-222

Atkinson CA, Jolley DF, Simpson SL (2007) Effect of overlying water $\mathrm{pH}$, dissolved oxygen, salinity and sediment disturbances on metal release and sequestration from metal contaminated marine sediments. Chemosphere 69: 1428-1437

Baars O, Croot PL (2015) Dissolved cobalt speciation and reactivity in the eastern tropical North Atlantic. Mar Chem 173:310-319

Biller DV, Bruland KW (2012) Analysis of Mn, Fe, Co, Ni, Cu, $\mathrm{Zn}, \mathrm{Cd}$, and $\mathrm{Pb}$ in seawater using the Nobias-chelate PA1 resin and magnetic sector inductively coupled plasma mass spectrometry (ICP-MS). Mar Chem 130-131:12-20

Boisvert S, Joly D, Leclerc S, Govindachary S, Harnois J, Carpentier R (2007) Inhibition of the oxygen-evolving complex of photosystem II and depletion of extrinsic polypeptides by nickel. Biometals 20:879-889

* Brand LE, Sunda WG, Guillard RRL (1986) Reduction of marine phytoplankton reproduction rates by copper and cadmium. J Exp Mar Biol Ecol 96:225-250

Caldeira K, Wickett ME (2005) Ocean model predictions of chemistry changes from carbon dioxide emissions to the atmosphere and ocean. J Geophys Res 110:1-12

Connell SD, Russell BD (2010) The direct effects of increasing $\mathrm{CO}_{2}$ and temperature on non-calcifying organisms: increasing the potential for phase shifts in kelp forests. Proc R Soc B 277:1409-1415

* Cornwall CE, Hurd CL (2016) Experimental design in ocean acidification research: problems and solutions. ICES J Mar Sci 73:572-581

* De Schamphelaere KAC, Stauber JL, Wilde KL, Markich SJ and others (2005) Toward a biotic ligand model for freshwater green algae: surface-bound and internal copper are better predictors of toxicity than free $\mathrm{Cu}^{2+}$-ion activity when $\mathrm{pH}$ is varied. Environ Sci Technol 39:2067-2072

* Domingos RF, Gélabert A, Carreira S, Cordeiro A, Sivry Y, Benedetti MF (2015) Metals in the aquatic environment-interactions and implications for the speciation and bioavailability: a critical overview. Aquat Geochem 21:231-257

* Doney SC, Fabry VJ, Feely RA, Kleypas JA (2009) Ocean acidification: the other $\mathrm{CO}_{2}$ problem. Annu Rev Mar Sci 1:169-192

Duce RA, Tindale NW (1991) Atmospheric transport of iron and its deposition in the ocean. Limnol Oceanogr 36: 1715-1726
Ebenezer V, Ki JS (2012) Evaluation of the sub-lethal toxicity of $\mathrm{Cu}, \mathrm{Pb}$, bisphenol $\mathrm{A}$ and polychlorinated biphenyl to the marine dinoflagellate Cochlodinium polykrikoides. Algae 27:63-70

Echeveste P, Agustí S, Tovar-Sánchez A (2012) Toxic thresholds of cadmium and lead to oceanic phytoplankton: cell size and ocean basin-dependent effects. Environ Toxicol Chem 31:1887-1894

Eggleton J, Thomas KV (2004) A review of factors affecting the release and bioavailability of contaminants during sediment disturbance events. Environ Int 30:973-980

Emery KO (1956) Sediments and water of Persian Gulf. Bull Am Assoc Pet Geol 40:2354-2383

Fischer AC, Kroon JJ, Verburg TG, Teunissen T, Wolterbeek HT (2007) On the relevance of iron adsorption to container materials in small-volume experiments on iron marine chemistry: ${ }^{55} \mathrm{Fe}$-aided assessment of capacity, affinity and kinetics. Mar Chem 107:533-546

* Gaillardet J, Dupré B, Louvat P, Allègre CJ (1999) Global silicate weathering and $\mathrm{CO}_{2}$ consumption rates deduced from the chemistry of large rivers. Chem Geol 159:3-30

* Geyer WR, Hill PS, Kineke GC (2004) The transport, transformation and dispersal of sediment by buoyant coastal flows. Cont Shelf Res 24:927-949

*Gobler CJ, Berry DL, Anderson OR, Burson A and others (2008) Characterization, dynamics, and ecological impacts of harmful Cochlodinium polykrikoides blooms on eastern Long Island, NY, USA. Harmful Algae 7:293-307

Gorbunov MY, Falkowski PG (2004) Fluorescence Induction and Relaxation (FIRe) technique and instrumentation for monitoring photosynthetic processes and primary production in aquatic ecosystems. In: van der Est A, Bruce D (eds) Photosynthesis: fundamental aspects to global perspectives. Allen Press, Montreal, p 1029-1031

*Gorbunov MY, Kolber ZS, Lesser MP, Falkowski PG (2001) Photosynthesis and photoprotection in symbiotic corals. Limnol Oceanogr 46:75-85

*Guillard RRL, Hargraves PE (1993) Stichochrysis immobilis is a diatom, not a chrysophyte. Phycologia 32:234-236

*Guinotte JM, Fabry VJ (2008) Ocean acidification and its potential effects on marine ecosystems. Ann NY Acad Sci 1134:320-342

*Halpern BS, Walbridge S, Selkoe KA, Kappel CV and others (2008) A global map of human impact on marine ecosystems. Science 319:948-952

*Hanghøj K, Kelemen PB, Hassler D, Godard M (2010) Composition and genesis of depleted mantle peridotites from the Wadi Tayin Massif, Oman ophiolite; major and trace element geochemistry, and Os isotope and PGE systematics. J Petrol 51:201-227

*Herzi FH, Jean N, Zhao H, Mounier S, Mabrouk HH, Hlaili AS (2013) Copper and cadmium effects on growth and extracellular exudation of the marine toxic dinoflagellate Alexandrium catenella: 3D-fluorescence spectroscopy approach. Chemosphere 93:1230-1239

*Ho TY (2013) Nickel limitation of nitrogen fixation in Trichodesmium. Limnol Oceanogr 58:112-120

* Ho TY, Chu TH, Hu CL (2013) Interrelated influence of light and Ni on Trichodesmium growth. Front Microbiol 4:139

*Hoffmann LJ, Breitbarth E, Boyd PW, Hunter KA (2012) Influence of ocean warming and acidification on trace metal biogeochemistry. Mar Ecol Prog Ser 470:191-205

Huot Y, Babin M (2011) Overview of fluorescence protocols: theory, basic concepts, and practice. In: Suggett DJ, Prasil O, Borowitzka MA (eds) Chlorophyll a fluores- 
cence in aquatic sciences: methods and applications. Springer, Dordrecht, p 31-74

IPCC (2013) Long-term climate change: projections, commitments and irreversibility. In: Stocker TF, Qin D, Plattner GK, Tignor $\mathrm{M}$ and others (eds) Climate change 2013: the physical science basis. Contribution of Working Group I to the Fifth Assessment Report of the Intergovernmental Panel on Climate Change. Cambridge University Press, Cambridge, p 1029-1136

Ito A (2007) Simulated impacts of climate and land-cover change on soil erosion and implication for the carbon cycle, 1901 to 2100. Geophys Res Lett 34:L09403

Iwataki M, Kawami H, Mizushima K, Mikulski CM and others (2008) Phylogenetic relationships in the harmful dinoflagellate Cochlodinium polykrikoides (Gymnodiniales, Dinophyceae) inferred from LSU rDNA sequences. Harmful Algae 7:271-277

JGOFS (1996) Measurement of chlorophyll $a$ and phaeopigments by fluorometric analysis. In: Knap A, Michaels A, Close A, Ducklow H, Dickson A (eds) Protocols for the Joint Global Ocean Flux Study (JGOFS) core measurements. UNESCO, Bergen, p 119-122

Jickells TD, An ZS, Andersen KK, Baker AR and others (2005) Global iron connections between desert dust, ocean biogeochemistry, and climate. Science 308: $67-71$

* Jordi A, Basterretxea G, Tovar-Sánchez A, Alastuey A, Querol X (2012) Copper aerosols inhibit phytoplankton growth in the Mediterranean Sea. Proc Natl Acad Sci USA 109:21246-21249

Mackey KRM, van Dijken GL, Mazloom S, Erhardt AM, Ryan J, Arrigo KR, Paytan A (2010) Influence of atmospheric nutrients on primary productivity in a coastal upwelling region. Glob Biogeochem Cycles 24:GB4027

* Mackey KRM, Buck KN, Casey JR, Cid A, Lomas MW, Sohrin Y, Paytan A (2012) Phytoplankton responses to atmospheric metal deposition in the coastal and openocean Sargasso Sea. Front Microbiol 3:359

* Mackey KRM, Chien CT, Post AF, Saito MA, Paytan A (2015) Rapid and gradual modes of aerosol trace metal dissolution in seawater. Front Microbiol 5:794

Mahowald NM, Kloster S, Engelstaedter S, Moore JK and others (2010) Observed 20th century desert dust variability: impact on climate and biogeochemistry. Atmos Chem Phys 10:10875-10893

Martin JH (1990) Glacial-interglacial $\mathrm{CO}_{2}$ change: the iron hypothesis. Paleoceanography 5:1-13

* Mélançon J, Levasseur M, Lizotte M, Scarratt M and others (2015) Effects of dust additions on phytoplankton growth and DMS production in high $\mathrm{CO}_{2}$ northeast Pacific HNLC waters. Biogeosci Discuss 12:12281-12319

* Meyer JS, Santore RC, Bobbitt JP, Debrey LD and others (1999) Binding of nickel and copper to fish gills predicts toxicity when water hardness varies, but free-ion activity does not. Environ Sci Technol 33:913-916

Miao AJ, Wang WX, Juneau P (2005) Comparison of Cd, Cu, and $\mathrm{Zn}$ toxic effects on four marine phytoplankton by pulse-amplitude-modulated fluorometry. Environ Toxicol Chem 24:2603-2611

* Millero FJ, Woosley R, Ditrolio B, Waters J (2009) Effect of ocean acidification on the speciation of metals in seawater. Oceanography 22:72-85

Milne A, Landing WM, Bizimis M, Morton PL (2010) Determination of $\mathrm{Mn}, \mathrm{Fe}, \mathrm{Co}, \mathrm{Ni}, \mathrm{Cu}, \mathrm{Zn}, \mathrm{Cd}$ and $\mathrm{Pb}$ in seawater using high resolution magnetic sector inductively coupled mass spectrometry (HR-ICP-MS). Anal Chim Acta 665:200-207

Modaihsh AS (1997) Characteristics and composition of the falling dust sediments on Riyadh city, Saudi Arabia. J Arid Environ 36:211-223

Moore CM, Mills MM, Achterberg EP, Geider RJ and others (2009) Large-scale distribution of Atlantic nitrogen fixation controlled by iron availability. Nat Geosci 2:867-871

* Morel FMM, Price NM (2003) The biogeochemical cycles of trace metals in the ocean. Science 300:944-947

* Morton PL, Landing WM, Hsu S, Milne A and others (2013) Methods for the sampling and analysis of marine aerosols: results from the 2008 GEOTRACES aerosol intercalibration experiment. Limnol Oceanogr Methods 11:62-78

*Paytan A, Mackey KRM, Chen Y, Lima ID and others (2009) Toxicity of atmospheric aerosols on marine phytoplankton. Proc Natl Acad Sci USA 106:4601-4605

* Perreault F, Dionne J, Didur O, Juneau P, Popovic R (2011) Effect of cadmium on photosystem II activity in Chlamydomonas reinhardtii: alteration of O-J-I-P fluorescence transients indicating the change of apparent activation energies within photosystem II. Photosynth Res 107: 151-157

Pilson MEQ (1998) An introduction to the chemistry of the sea. Prentice Hall, Upper Saddle River, NJ

* Richlen ML, Morton SL, Jamali EA, Rajan A, Anderson DM (2010) The catastrophic 2008-2009 red tide in the Arabian Gulf region, with observations on the identification and phylogeny of the fish-killing dinoflagellate Cochlodinium polykrikoides. Harmful Algae 9:163-172

* Ritchie RJ (2008) Fitting light saturation curves measured using modulation fluorometry. Photosynth Res 96: 201-215

Rudnick RL, Gao S (2003) Composition of the continental crust. In: Rudnick RL (ed) The crust. Elsevier, Amsterdam, p 1-64

Saeedi H, Kamrani E, Matsuoka K (2011) Catastrophic impact of red tides of Cochlodinium polykrikoides on the razor clam Solen dactylus in coastal waters of the northern Persian Gulf. J Persian Gulf 2:13-19

Shi D, Xu Y, Hopkinson BM, Morel FMM (2010) Effect of ocean acidification on iron availability to marine phytoplankton. Science 327:676-679

* Srinivas B, Sarin MM (2013) Atmospheric deposition of N, P and $\mathrm{Fe}$ to the Northern Indian Ocean: implications to Cand N-fixation. Sci Total Environ 456-457:104-114

* Strong AL, Kroeker KJ, Teneva LT, Mease LA, Kelly RP (2014) Ocean acidification 2.0: managing our changing coastal ocean chemistry. Bioscience 64:581-592

Suggett DJ, Moore CM, Geider RJ (2011) Estimating aquatic productivity from active fluorescence measurements. In: Suggett DJ, Prasil O, Borowitzka MA (eds) Chlorophyll a fluorescence in aquatic sciences: methods and applications. Springer, Dordrecht, p 103-127

Sunda WG (1989) Trace metal interactions with marine phytoplankton. Biol Oceanogr 6:411-442

Sunda WG (1994) Trace metal/phytoplankton interactions in the sea. In: Bidoglio G, Stumm W (eds) Chemistry of aquatic systems: local and global perspectives. ECSC, EEC, EAEC, Brussels, p 213-247

Sunda WG, Huntsman SA (1998) Processes regulating cellular metal accumulation and physiological effects: phytoplankton as model systems. Sci Total Environ 219: 165-181 
Sunda WG, Price NM, Morel FMM (2005) Trace metal ion buffers and their use in culture studies. In: Andersen RA (ed) Algal culturing techniques. Elsevier, Burlington, MA, p 35-63

Tang YZ, Gobler CJ (2009) Cochlodinium polykrikoides blooms and clonal isolates from the northwest Atlantic coast cause rapid mortality in larvae of multiple bivalve species. Mar Biol 156:2601-2611

Tindale NW, Pease PP (1999) Aerosols over the Arabian Sea: atmospheric transport pathways and concentrations of dust and sea salt. Deep Sea Res II 46: $1577-1595$

Editorial responsibility: Zoe Finkel, Sackville, New Brunswick, Canada
Turner A, Millward GE (2002) Suspended particles: their role in estuarine biogeochemical cycles. Estuar Coast Shelf Sci 55:857-883

* Twining BS, Baines SB (2013) The trace metal composition of marine phytoplankton. Annu Rev Mar Sci 5:191-215

* Xu Y, Shi D, Aristilde L, Morel FMM (2012) The effect of pH on the uptake of zinc and cadmium in marine phytoplankton: possible role of weak complexes. Limnol Oceanogr 57:293-304

Yang D, Kanae S, Oki T, Koike T, Musiake K (2003) Global potential soil erosion with reference to land use and climate changes. Hydrol Process 17:2913-2928

Submitted: March 21, 2016; Accepted: June 28, 2017

Proofs received from author(s): August 30, 2017 